\title{
LATE REPAIR OF THE CALCANEAL TENDON WITH CARBON FIBRE
}

\author{
C. B. HOWARD, I. WINSTON, W. BELL, I. MACKIE, D. H. R. JENKINS
}

From Welsh National School of Medicine, Cardiff

\begin{abstract}
Ruptures of the calcaneal tendon which present late may be repaired using carbon fibre to induce a neotendon. The operative technique is described and the results of five cases reviewed. The average muscle power obtained was $88 \%$ of normal, and the thickness of the neotendon was $148 \%$ of that of the normal side. It would appear that this tendon formation in man is comparable to that previously described in sheep.
\end{abstract}

The results of untreated ruptures of the calcaneal tendon are widely accepted as poor, leaving the patient with a considerable degree of disability (Bosworth 1956). While there are arguments as to whether ruptures presenting early should be treated surgically or conservatively (Inglis et al. 1976), it is conceded that ruptures which present late can only be treated surgically. Because the proximal end of the tendon retracts, all methods have involved using tendon or fascial grafts. The reported results have been on small numbers of cases and most have been based on subjective assessment (Zadek 1940; Tobin 1953; Lynn 1966; Abraham and Pankovich 1975).

In 1977 Jenkins et al. reported the use of carbon fibre as a method of inducing a neotendon in the calcaneal tendon of sheep. We wish to report the results of treatment when carbon fibre was used in man to produce a neotendon in ruptures of the calcaneal tendon presenting late.

\section{CLINICAL MATERIAL AND METHODS}

Five patients who had been treated late for ruptures of the calcaneal tendon were available for review. They were all male, aged between 32 and 76 years (average 51 years). The delay between injury and operation was from six weeks to nine months (average six months), and the follow-up period was from 4 to 19 months (average 13 months) (Table I).

C. B. Howard, FRCS, Lecturer in Orthopaedics, Welsh National School of Medicine

Prince of Wales Orthopaedic Hospital, Rhydlafar, Cardiff CF5 6XG, Wales.

I. Winston. FRC S. Orthopaedic Registrar

Bristol Royal Infirmary, Marlborough Street, Bristol BS2 $8 \mathrm{HW}$ England.

W. Bell, MEd, DPE

Institute of Higher Education, Cyncoed, Cardiff CF2 6XD. Wales.

I. Mackie, FRCS. Senior Registrar

Royal Infirmary, Cardiff CF2 IS2, Wales

D. H. R. Jenkins, FRCS. Consultant Surgeon in Orthopaedic and Traumatic Surgery

University Hospital of Wales. Heath Park. Cardiff CF4 4XW, Wales.

Requests for reprints should be sent to $\mathrm{MrC}$. B. Howard.

1984 British Editorial Society of Bone and Joint Surgery

$0301620 \times 842039 \$ 2.00$
Table I. Delay before operation and length of follow-up afterwards

\begin{tabular}{|llll|}
\hline Case & $\begin{array}{l}\text { Age } \\
\text { (years) }\end{array}$ & $\begin{array}{l}\text { Delay between injury } \\
\text { and operation } \\
\text { (months) }\end{array}$ & $\begin{array}{l}\text { Length of } \\
\text { follow-up } \\
\text { (months) }\end{array}$ \\
\hline 1 & 76 & 6 & 4 \\
2 & 46 & 1.5 & 15 \\
3 & 69 & 9 & 15 \\
4 & 32 & 5 & 10 \\
5 & 34 & 9 & 19 \\
\hline
\end{tabular}

The patients were assessed by measuring the power of plantarflexion, the diameter of the calf, the ability to tiptoe and the thickness of the tendon (measured at a standard distance from the floor); these measurements were compared with those on the uninjured leg. The power of plantarflexion was measured on the supine patient by placing a sling around the foot distal to the head of the first metatarsal and attaching it to a strain gauge. The patient was then asked to plantarflex the foot; the maximum readings on three occasions were taken and averaged. The patients were then asked whether they had returned to their full normal activities and to give a subjective assessment of the procedure--excellent, good, fair or poor.

Operative technique. The calcaneal tendon was approached from the medial side by a longitudinal incision. If the defect in the tendon had filled in with scar tissue, this was cut back until normal tendon was found. In one patient a hole was drilled through the os calcis and through it one end of the carbon fibre (supplied by Johnson \& Johnson) was passed. In the other four patients there was sufficient length of tendon distally to allow the carbon fibre to be inserted in the Bunnell-type manner; the two free ends of the carbon fibre were then woven in and out of the proximal tendon, with the foot placed in equinus, in as much tension as was possible.

The wound was closed in two layers and a belowknee plaster was applied. At the end of one month the 
Table II. Power of plantarflexion

\begin{tabular}{|c|c|c|c|c|c|c|c|c|c|}
\hline \multirow[b]{2}{*}{ Case } & \multicolumn{4}{|c|}{ Operated side $(k g)$} & \multicolumn{4}{|c|}{ Normal side $(\boldsymbol{k g})$} & \multirow{2}{*}{$\begin{array}{l}\text { Operated/ } \\
\text { normal } \\
(\%)\end{array}$} \\
\hline & 1 & 2 & 3 & Average & 1 & 2 & 3 & Average & \\
\hline 1 & 13 & 16 & 15 & 14.7 & 19 & 20 & 24 & 21.0 & 70) \\
\hline 2 & 27 & 32 & 27 & 28.7 & 34 & 33 & 30 & 32.3 & 89 \\
\hline 3 & 41 & 44 & 41 & 42.0 & 42 & 45 & 40 & 42.3 & 99 \\
\hline 4 & 64 & 59 & 70 & 64.3 & 65 & 67 & 74 & 68.7 & 94 \\
\hline 5 & 58 & 54 & 51 & 54.3 & 67 & 60) & 62 & 63.0 & 86 \\
\hline
\end{tabular}

Average muscle power of the five patients was $88^{\circ}$ of normal

plaster was changed and the foot brought up almost to the plantargrade position. After a further month the patient was allowed out of plaster and mobilisation was started under the supervision of a physiotherapist.

\section{RESULTS}

All the patients achieved excellent results. At review all but one had returned to those activities which they had enjoyed before the rupture. This one patient still had a problem with the wound and felt unhappy about returning to jogging.

The power of plantarflexion on the injured side ranged from $70 \%$ to $99 \%$ of that on the uninjured side (Table II). The calf width ranged from $89 \%$ to $98 \%$ of the normal side (Table III). The maximum which the patient standing on tiptoe could raise the heel from the ground ranged from $79 \%$ to $87.5 \%$ of the normal (Table IV; Figs 1 and 2). The thickness of the tendons measured at $7.5 \mathrm{~cm}$ from the floor, with the patient standing with the feet flat, ranged from $120 \%$ to $167 \%$ as compared with the uninjured side (Table V; Fig. 3); this indicated a significant degree of neotendon formation. All the patients graded the functional results as excellent, but one patient had some reservations because the wound was not fully healed.

Complications. Two patients complained of some stiffness, but this wore off after walking 100 metres or so.
Table III. Calf width

\begin{tabular}{|llll|}
\hline Case & $\begin{array}{l}\text { Operated side } \\
(\mathrm{cm})\end{array}$ & $\begin{array}{l}\text { Normal side } \\
(\mathrm{cm})\end{array}$ & $\begin{array}{l}\text { Operated/normal } \\
(\%)\end{array}$ \\
\hline 1 & 32 & 32.5 & 98 \\
2 & 26 & 26.5 & 98 \\
3 & 26 & 29 & 90 \\
4 & 40.5 & 42 & 96 \\
5 & 32 & 36 & 89 \\
\hline
\end{tabular}

Average calf width was $94^{\circ}$ of normal

Table IV. Distance the heel could be raised when standing on tiptoe

\begin{tabular}{|llll|}
\hline Case & $\begin{array}{l}\text { Operated side } \\
(\mathrm{cm})\end{array}$ & $\begin{array}{l}\text { Normal side } \\
(\mathrm{cm})\end{array}$ & $\begin{array}{l}\text { Operated/normal } \\
(\%)\end{array}$ \\
\hline 1 & 5.2 & 6.5 & 80 \\
2 & 7 & 8 & 87.5 \\
3 & 5.5 & 7 & 79 \\
4 & 7 & 8 & 87.5 \\
5 & 11.5 & 14 & 82 \\
\hline
\end{tabular}

Average distance heel could be raised was $83^{\circ}{ }_{0}$ of normal

Table V. Thickness of the calcaneal tendon $(7.5 \mathrm{~cm}$ from the sole $)$

\begin{tabular}{|llll|}
\hline Case & $\begin{array}{l}\text { Operated side } \\
(\mathrm{cm})\end{array}$ & $\begin{array}{l}\text { Normal side } \\
(\mathrm{cm})\end{array}$ & $\begin{array}{l}\text { Operated/normal } \\
(\%)\end{array}$ \\
\hline 1 & 3 & 2.5 & 120 \\
2 & 2.3 & 1.5 & 153 \\
3 & 3 & 1.9 & 158 \\
4 & 3.5 & 2.1 & 167 \\
5 & 2.6 & 1.8 & 144 \\
\hline
\end{tabular}

Average thickness of the calcaneal tendon was $148^{\circ}$ of normal

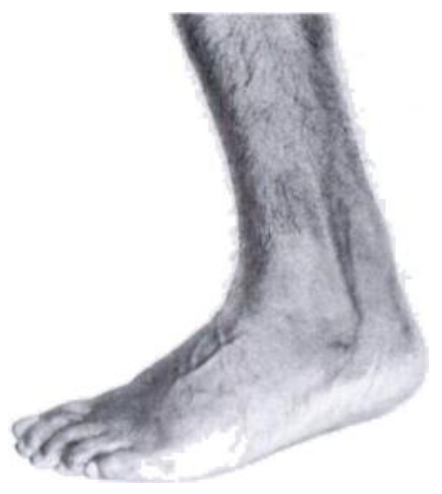

Fig. I

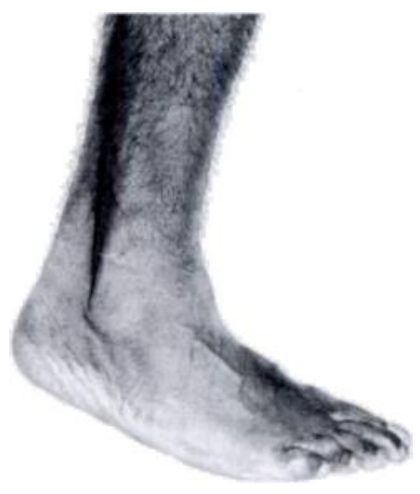

Fig. 2

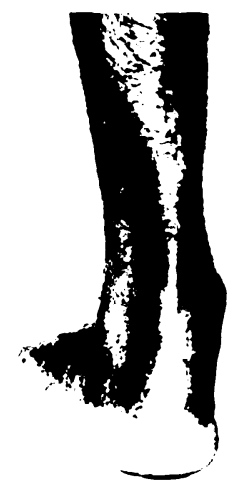

Fig. 3

Case 2. Figure I Maximum height the heel can be raised on the operated side. Figure 2-Maximum height the heel can be raised on the normal side. Figure 3 Photograph showing the increased thickness of the calcaneal tendon on the operated (left) side. 
One patient had some eczematoid skin over the lower part of the leg, but he had only been out of plaster for two months. In another patient the wound was still not fully healed after 10 months, although the unhealed area was only superficial and had not stopped him from returning to work as a maintenance fitter. He was seen three months after this review; the wound is now fully healed and he has been discharged.

\section{DISCUSSION}

Published results of the treatment of late presentation of ruptured calcaneal tendons are scanty and mostly subjective. Inglis et al. (1976) compared surgically and non-surgically treated patients using a Cybex II dynamometer. Among the surgically treated patients 14 had been operated on after one or more months had elapsed since injury, and a variety of surgical techniques had been employed. The patients regained $85 \%$ of their muscle power compared with the uninjured side; this is comparable with the $88 \%$ obtained by our patients (Table II).

Subjective assessment by patients is notoriously suspect. However, all our patients were most emphatic in their enthusiasm for the procedure (including the patient whose wound took a year to heal).

It would appear from our results that neotendon formation in response to a carbon-fibre scaffold in the calcaneal tendon is comparable in the human subject to that originally described in the sheep. We would therefore recommend this method of repair as its results are excellent and it is technically a much simpler procedure than conventional techniques employing the patient's own tissues.

\section{REFERENCES}

Abraham E, Pankovich AM. Neglected rupture of the Achilles tendon: treatment by V-Y tendinous flap. J Bone Joint Surg [Am] 1975:57-A: 253-5.

Bosworth DM. Repair of defects in the tendo achillis. J Bone Joint Surg [ Am] 1956:38-A : 111-4.

Inglis AE, Scott WN, Sculco TP, Patterson AH. Ruptures of the tendo Achillis. An objective assessment of surgical and non-surgical treatment. J Bone Joint Surg [ Am] 1976:58-A:990-3.

Jenkins DHR, Foster IW, McKibbin B, Ráliš ZA. Induction of tendon and ligament formation by carbon implants. J Bone Joint Surg [Br] 1977:59-B:53-7.

Lynn TA. Repair of the torn Achilles tendon, using plantaris tendon as a reinforcing membrane. J Bone Joint Surg [Am] 1966:48-A:268-72.

Tobin WJ. Repair of neglected ruptured and severed Achilles tendon. Am Surg 1953: 19:514-22.

Zadek I. Repair of old rupture of the tendo Achillis by means of fascia lata: report of a case. J Bone Joint Surg 1940:22:1070-1. 